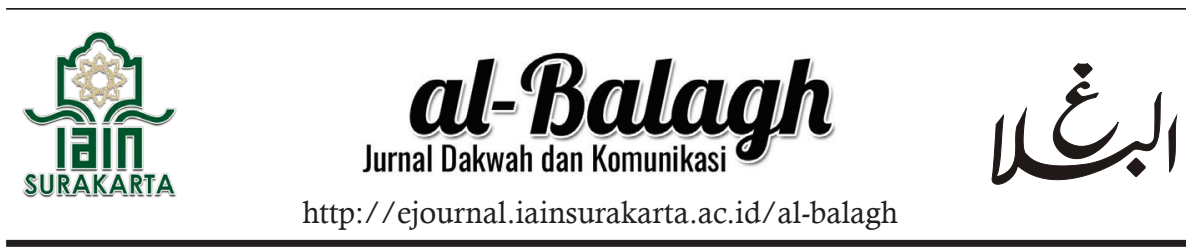

\title{
FORGIVENESS, SELF-ESTEEM, AND RESILIENCE IN ADULT VICTIMS OF BULLYING
}

\author{
Dinu Hafidh Muvariz \\ Hanifah Nur Fitriani \\ Indah Nisrina \\ Fuad Nashori* \\ Universitas Islam Indonesia, Yogyakarta
}

Keywords:

adult victim of bullying; forgiveness; resilience; self-esteem

\begin{abstract}
Apart from occurring in children and adolescents, bullying also occurs in adult groups. The impact on adults includes psychological, physical, social, and economic dimensions. The main impact that often affects victims of adult bullying is emotional problem. Forgiveness and self-esteem are indicated to be two variables that influence resilience in victims of adult bullying. This study aimed to determine the effect of forgiveness and self-esteem on resilience in 94 adults who are victims of bullying. The analysis was performed using regression analysis. The result obtained in this study was that forgiveness and selfesteem affect $49.5 \%$ ( $R$ Square $=0.495$, Sig. $=0.000)$ of the resilience of bullying victims. Thus, forgiveness and self-esteem are essential keys to increase the resilience of victims of bullying so that they are not prone to experiencing mental disorders.
\end{abstract}

Correspondence:

e-mail: dinuhafidh@gmail.com hanifahnurfitriani99@gmail.com indahinsrina13@yahoo.co.id *fuadnashori@uii.ac.id 


\begin{tabular}{l}
\hline \\
\hline Kata kunci: \\
korban \\
perundungan \\
dewasa; \\
pemafaan; \\
resiliensi; harga \\
diri \\
\hline
\end{tabular}

\begin{abstract}
Abstrak
Selain terjadi pada anak dan remaja, perundungan juga terjadi pada kelompok orang dewasa. Dampak yang terjadi pada orang dewasa mencakup dimensi psikologis, fisik, sosial, dan ekonomi. Dampak utama yang sering terjadi pada korban perundungan dewasa ada pada emosi. Pemaafan dan harga diri diindikasi menjadi dua hal yang memberikan pengaruh terhadap resiliensi pada korban perundungan dewasa. Penelitian ini bertujuan untuk mengetahui pengaruh pemaafan dan harga diri terhadap resiliensi pada 94 orang dewasa yang menjadi korban perundungan dewasa. Analisis yang dilakukan menggunakan analisis regresi. Hasil yang didapatkan pada penelitian ini adalah pemaafan dan harga diri memberikan pengaruh sebesar $49,5 \%$ ( $R$ Square $=0,495$, Sig. $=0,000$ ) terhadap resiliensi korban perundungan. Dengan demikian, pemaafan dan harga diri menjadi kunci penting untuk meningkatkan resiliensi korban perundungan sehingga korban perundungan tidak rentan mengalami gangguan kejiwaan.
\end{abstract}

\title{
How to cite this (APA $7^{\text {th }}$ Edition):
}

Muvariz, D. H., Fitriani, H. N., Nisrina, I., \& Nashori, F. (2020). Forgiveness, Self-Esteem, And Resilience In Adult Victims Of Bullying. Al-Balagh: Jurnal Dakwah Dan Komunikasi, 5(2), 165-192. https://doi.org/10.22515/ al-balagh.v5i2.2375

\section{INTRODUCTION}

Bullying is a common phenomenon. Bullying can be interpreted as an aggressive behavior that is carried out repeatedly and involves two parties who have unequal power (Smith, 2016). Nearly all the time the news presents bullying phenomenon. The Indonesian Child Protection Commission's statistical data stated that there were 26,000 complaints of bullying cases during 2011-2017. This number of cases indicates that bullying is still an unresolved phenomenonThere are several forms of 
bullying; e.g., bullying in physical form (hitting, kicking), verbal or verbal abuse (taunting, scolding, and making fun of), and bullying in the form of antisocial (isolating others) (Hatta, 2018).

Most bullying cases occur in children. However, bullying can also occur in adult-aged individuals. Zhang (2017) and Wolke and Lereya (2015) stated that bullying behavior can occur in students and groups of adults. Another discovery by Hidayati and Rahayuningsih (2014) was that adult bullying also occurs in the workplace. Based on these facts, it can be concluded that bullying can occur in groups of adults across environments.

Adults in the 18-50 year age group who are victims of bullying are predisposed to several psychological, physical, social, and economic problems (Wolke \& Lereya, 2015). The impacts felt by victims of bullying are in the form of psychological disorders, depression, and loneliness. Bullying victims are also prone to psychosomatic disorders, emotional problems, and suicidal thoughts. These impacts will continue to be felt by victims of bullying for a long time (Woods et al., 2009; Prasetyo, 2014; Aalsma \& Brown, 2008). Based on this data, it can be said that one of the problems that occur in victims of bullying is negative emotions. The emotional problems faced by victims of bullying are caused by victims' limited ability to recognize and control their emotions (Woods et al., 2009).

The emergence of negative emotions in the bullying victim indicates the victim's low resilience. Resilience has many definitions from various perspectives and contexts (Southwick, Bonanno, Masten, Panter-Brick, \& Yehuda, 2014). However, resilience can be interpreted as an individual's persistence to return to healthy mental state despite having difficult experiences to accept and deal with (Herrman et al., 2011). Negative emotions that indicate low resilience are caused by individuals low capacity to tolerate negative feelings that arise due to bullying. As it is known, one of the factors contributing to a person's resilience is tolerance of negative 
feelings (Connor \& Davidson, 2003). When an individual is able to tolerate negative feelings, the person will have strong resilience. However, if the individual cannot reduce the presence of negative emotions within oneself, it will lead to weak individual resilience.

The emergence of negative emotions in the victim of bullying can also indicate an imbalance in self-esteem. Self-esteem can be interpreted as the overall positive evaluation of an individual about oneself (Cast $\&$ Burke, 2002). The emergence of low self-esteem is one factor that disrupts a person's resilience. It is because self-esteem may be a factor affecting resilience for someone who experiences anxiety or depression in the future (Henriksen, 2016; Henriksen et al., 2017).

The correlation between self-esteem and resilience is also supported by research results, which showed that people who have low self-esteem and helplessness will also have low resilience. The correlation between selfesteem and resilience occurs because someone who has high and positive self-esteem will also have a high level of self-confidence and belief. This high level of self-confidence and belief causes a person to be motivated to face problems and difficulties (Karatas \& Cakar, 2011). However, several other research results showed no direct correlation between self-esteem and resilience. Nonetheless, the two variables simultaneously became predictors of increased performance and decreased adolescents' unsafe behavior (Kwek, Bui, Rynne, \& So, 2013; Veselska et al., 2009). It also shows that self-esteem can increase resilience and keep a person away from risky behaviors.

Scientific studies also show a corrrelation between forgiveness and resilience. A person who tends to forgive will always exercise control over negative feelings or affections. It pertains with one of the aspects of resilience, namely emotion regulation which is related to how someone is managing the emotions they feel, both positive and negative (Reivich \& Shatté, 2002). A study by Saffarinia, Mohammadi, and Afshar (2016) also 168 
showed that the components in forgiveness; i.e.,re-communication and control of revenge, control of resentment, and realistic understanding; are positively related to resilience. This finding means that the dimension of control over things felt by someone who has forgiveness is an indication of emotional stability. Besides, forgiveness can also benefit someone in facing difficult situations.

The affection aspect of forgiveness is also a factor in oneself to be able to face difficult situations (Saputro \& Nashori, 2017). A literature review results showed that forgiveness can give human the ability to overcome difficulties caused by oneself (Egan \& Todorov, 2009). Egan and Todorov (2009) also added that people who condone other people's bad behavior tend to have less anxiety. On the other hand, depressed people with low anxiety level tend to have more resilient and are indicated to undergo psychotherapy or treatment better (Min, Lee, Lee, Lee, \& Chae, 2012). Apart from the direct correlation between forgiveness and resilience, self-forgiveness and resilience also contribute to the prevention of suicidal tendency and self-harm behavior. This condition occurs because there is emotional coping in forgiveness (Nagra, Lin, \& Upthegrove, 2016).

Referring to the various research results, it can be assumed that forgiveness and self-esteem have a positive correlation with resilience in adult victims of bullying. The negative emotions that often emerge in bullying victim, a lack of control over them, and the person's low self-confidence to overcome the difficulties resulting from bullying are indicators of low resilience in bullying victims. The assumptions that the emotional stability mechanism obtained through control over the things felt by someone who implements forgiveness, and that self-esteem is directly proportional to a person's conviction in ability to face difficult situations can be indicators for forgiveness and self-esteem. Thus, this mechanism is considered to increase a person's resilience. 
Studies about resilience, forgiveness, and self-esteem had been conducted multiple times, for example, research by Jaufalaily and Himam (2017) and research by Soni (2015). However, most studies about resilience of bullying victims tend to focus more on children, adolescents, and the effects of experiencing bullying in childhood on development in adulthood (Copeland, Wolke, Angold, \& Costello, 2013; Watson, Rapee, \& Todorov, 2015; Wolke \& Lereya, 2015). Therefore, it is essential to examine the correlation between resilience, forgiveness, and self-esteem in individuals who are experiencing bullying in adulthood. Based on this, this study focused on adult victims of bullying. There has not been much research related to research on forgiveness, self-esteem, and resilience in adults who are victims of bullying, so far.

This study aimed to determine the effect of forgiveness and selfesteem on the resilience of adults who are victims of bullying. There were two hypotheses in this study, namely the alternative hypothesis and the null hypothesis. The alternative hypothesis in this study was that there is a correlation between forgiveness and self-esteem with resilience in adultindividuals who are victims of bullying. This study's null hypothesis was that there is no correlation or relationship between forgiveness and self-esteem with resilience in adult victims of bullying.

\section{METHODS}

This study used a quantitative approach. A quantitative approach is a research approach that involves calculation of numbers to determine the level of variables, either differences or correlations. This research used the correlational method because this study aimed to examine the correlation between forgiveness and self-esteem on resilience in adult individuals who are victims of bullying.

There were three variables examined in this research, namely forgiveness, self-esteem, and resilience. The operational definition of 
forgiveness is the individual's attitude to reduce negative thoughts and emotions and the urge to reciprocate others' behavior based on hatred. Forgiveness has three aspects: self-forgiveness, forgiveness of others, and forgiveness of situations. Forgiveness was measured using the Heartland Forgiveness Scale. The higher the measured score obtained by the individual, the higher the level of individual forgiveness. However, if the individual's measured score is low, it indicates that the level of individual forgiveness is also low.

The operational definition of self-esteem is the overall result of an individual's positive evaluation of oneself, which includes the individual's perception of their own self as a capable person and the individual's feeling that they are valuable. This self-esteem consists of aspects of selfcompetence and self-liking. Self-esteem in research subjects was measured using the Rosenberg Self-Esteem Scale. The higher the research subject's score indicates that the higher the level of self-esteem of the research subject. Conversely, based on the research subject's score, the lower the research subject's self-esteem.

The operational definition of resilience is the stamina or ability of an individual to survive, be brave, adapt, and rise to cope with difficult life pressures and become a more tenacious individual. Resilience is composed of several aspects, namely emotional regulation, impulse control, optimism, empathy, analysis of the causes of problems, self-efficacy, and improved positive aspects. The level of resilience in research subjects was measured using the Connor-Davidson Resilience Scale. The higher the research subject's score indicates that the level of research subject resilience is also high. However, when the scores produced by research subjects are low, research subject's resilience is also low.

Subjects in the study were 94 adults. The characteristics of the research subjects were victims of bullying, aged 17-25 years, education level from high school to undergraduate, and males and females. They lived in the Special Province of Yogyakarta, Indonesia. 
The data collection tools used in this study were three measuring instruments or scales: the forgiveness scale, the self-esteem scale, and the resilience scale. The scale used to measure forgiveness is adapted from Heartland Forgiveness Scale (Thompson et al., 2005) which had been translated into Indonesian. The scale used to measure resilience is the Connor-Davidson Resilience Scale (CD-RISC) (Connor \& Davidson, 2003). As for the scale to measure self-esteem, Rosenberg Self-Esteem Scale (Rosenberg, 1965) was used.

Heartland Forgiveness Scale contains 18 items or statement items. This scale contains three aspects, namely self-forgiveness, forgiveness of others, and forgiveness of situations. The estimated value of the reliability coefficient using Alpha Cronbach for Heartland Forgiveness Scale is 0.87 (Thompson et al., 2005).

Rosenberg Self-Esteem Scale (Rosenberg, 1965) contains ten items or statements. This scale is meant for measuring self-competence and self-liking. The estimated value of the reliability coefficient Alpha Cronbach Scale Heartland Forgiveness Scale is equal to 0.87 (Schmitt \& Allik, 2005).

Furthermore, the Connor-Davidson Resilience Scale (CD-RISC) consists of 25 items or statement items. This measuring tool is intended to measure individual resilience. The Cronbach Alpha internal consistency value is 0.89 , and the test-retest reliability of this scale, obtained from the interclass correlation, is 0.87 (Connor \& Davidson, 2003). Measuring instrument which has reliability coefficient more than 0.70 is considered to have high reliability (Azwar, 2016; Saifuddin, 2019, 2020; Kaplan \& Saccuzzo, 2017). Based on the measuring instruments' test results, it can be concluded that the instruments used in this study were reliable.

There were two types of analysis techniques used, namely assumption testing and hypothesis testing. This study's assumption test consisted of the normality test, linearity test, heteroscedasticity test, and multicollinearity test. The normality test aims to determine the distribution of 172 
research data to follow the standard curve or not. The linearity test aims to determine whether there is a linear correlation between the predictor and the criterion. The heteroscedasticity test aims to test whether there is a variance difference from the residual value in an observation or measurement period. If the variance of the residuals of an observation period is constant, it is considered as homoscedasticity or non-occurrence of heteroscedasticity. Data can be calculated by regression analysis if there is no heteroscedasticity. The multi-collinearity test aims to calculate the presence or absence of a correlation between one independent variable (predictor) and another. If there is no multi-collinearity, it means that there is no correlation between one independent variable and another. In this case, there should be no correlation between forgiveness and self-esteem. Hypothesis testing used multiple linear regression analysis. The various data analysis techniques were performed using the Statistical Product and Service Solutions (SPSS) software.

\section{RESULTS AND DISCUSSION}

\section{Research Results}

Before testing the hypothesis in the form of multiple linear regressions on the research data obtained, it is necessary to perform assumption tests. The first stage was to conduct a normality test, which aims to see the normality of the distribution of data that has been obtained. Based on the normality test results presented in table 1 , the normality coefficient was 0.982 with significance value amounting to 0.202 ( $p>0.05$ ). It means that the research data is normally distributed. 
Vol. 5, No. 2, July - December 2020, pp. 165 - 192, DOI: https:/ / doi.org/10.22515/al-balagh.v5i2.2375 ISSN: 2527-5704 (P) ISSN: 2527-5682 (E)

Table 1.

Normality Test Results

\begin{tabular}{|c|c|c|c|c|c|c|}
\hline & \multicolumn{3}{|c|}{ Kolmogorov-Smirnov $^{a}$} & \multicolumn{3}{|c|}{ Shapiro-Wilk } \\
\hline & Statistic & df & Sig. & Statistic & df & Sig. \\
\hline Resilience & .068 & 95 & $.200^{*}$ & .982 & 95 & .202 \\
\hline \multicolumn{7}{|c|}{ *. It is a lower bound of real significance. } \\
\hline a. Lilliefors & ificance Co & ection & & & & \\
\hline
\end{tabular}

The second assumption test is the linearity test for the dependent variable (resilience) and the independent variables (self-esteem and forgiveness). Based on the results of ANOVA in the table 2 and 3, it was found that the p-values of Resilience and Self-Esteem as well as Resilience Forgiveness were significant $(\mathrm{p}<0.01)$. It means that the correlation between resilience and self-esteem as well as forgiveness is linear.

Table 2.

Resilience and Self-Esteem Variable Linearity Test Results

\begin{tabular}{|c|c|c|c|c|c|c|c|}
\hline & & & $\begin{array}{l}\text { Sum of } \\
\text { Squares }\end{array}$ & df & $\begin{array}{l}\text { Mean } \\
\text { Square }\end{array}$ & $\mathrm{F}$ & Sig. \\
\hline \multirow{5}{*}{$\begin{array}{l}\text { Resilience } * \\
\text { Self-Esteem }\end{array}$} & \multirow{3}{*}{$\begin{array}{l}\text { Between } \\
\text { Groups }\end{array}$} & (Combined) & 8658.915 & 23 & 376.475 & 2.660 & .001 \\
\hline & & Linearity & 5847.022 & 1 & 5847.022 & 41.305 & .000 \\
\hline & & $\begin{array}{l}\text { Deviation } \\
\text { from } \\
\text { Linearity }\end{array}$ & 2811.893 & 22 & 127.813 & .903 & .591 \\
\hline & \multicolumn{2}{|c|}{ Within Groups } & 10050.517 & 71 & 141.557 & & \\
\hline & \multicolumn{2}{|l|}{ Total } & 18709.432 & 94 & & & \\
\hline
\end{tabular}


Table 3.

Results of the Linearity Test of Resilience and Forgiveness Variables

\begin{tabular}{|c|c|c|c|c|c|c|c|}
\hline & & & $\begin{array}{l}\text { Sum of } \\
\text { Squares }\end{array}$ & df & $\begin{array}{l}\text { Mean } \\
\text { Square }\end{array}$ & F & Sig. \\
\hline \multirow{5}{*}{$\begin{array}{l}\text { Resilience } * \\
\text { Forgiveness }\end{array}$} & \multirow{3}{*}{$\begin{array}{l}\text { Between } \\
\text { Groups }\end{array}$} & (Combined) & 12793.565 & 45 & 284.301 & 2.355 & .002 \\
\hline & & Linearity & 7486.229 & 1 & 7486.229 & 62.007 & .000 \\
\hline & & $\begin{array}{l}\text { Deviation from } \\
\text { Linearity }\end{array}$ & 5307.336 & 44 & 120.621 & .999 & .499 \\
\hline & \multicolumn{2}{|c|}{ Within Groups } & 5915.867 & 49 & 120.732 & & \\
\hline & \multicolumn{2}{|l|}{ Total } & 18709.432 & 94 & & & \\
\hline
\end{tabular}

The next step was to examine the presence or absence of multicollinearity among independent variables. It is known from the Tolerance and VIF values in table 4. The Tolerance figure obtained was $0.799(>0.1)$ and the VIF value obtained was 1.251 (value $<10$ ). It means that there is no multi-collinearity between the two independent variables.

Table 4.

Multi-collinearity Test Results

\begin{tabular}{|c|c|c|c|c|c|c|c|c|}
\hline \multicolumn{9}{|c|}{ Coefficients } \\
\hline & \multirow{2}{*}{ Model } & \multicolumn{2}{|c|}{$\begin{array}{l}\text { Unstandardized } \\
\text { Coefficients }\end{array}$} & \multirow{2}{*}{$\begin{array}{c}\begin{array}{c}\text { Standardized } \\
\text { Coefficients }\end{array} \\
\text { Beta }\end{array}$} & \multirow[t]{2}{*}{$\mathrm{t}$} & \multirow{2}{*}{ Sig. } & \multicolumn{2}{|c|}{ Collinearity Statistics } \\
\hline & & $\mathrm{B}$ & Std. Error & & & & Tolerance & VIF \\
\hline \multirow[t]{3}{*}{1} & (Constant) & 34.746 & 6.697 & & 5.189 & .000 & & \\
\hline & Self-Esteem & .885 & .213 & .345 & 4.161 & .000 & .799 & 1.251 \\
\hline & Pemaafan & .480 & .083 & .478 & 5.769 & .000 & .799 & 1.251 \\
\hline
\end{tabular}

a. Dependent Variable: Resiliensi

Next step was to test the heteroscedasticity assumption, which aims to determine the residuals' variance inequality for all observations in the regression model. If there is no similarity between the variance of the residuals, a regression test can be performed. Based on the results of assumption test (shown in table 5), the significance value is obtained. Selfesteem variable showed $\mathrm{p}=0.119(\mathrm{p}>0.05)$ and Forgiveness showed $\mathrm{p}$ 
Al-Balagh: Jurnal Dakwah dan Komunikasi,

Vol. 5, No. 2, July - December 2020, pp. 165 - 192, DOI: https:// doi.org/10.22515/al-balagh.v5i2.2375

ISSN: 2527-5704 (P) ISSN: 2527-5682 (E)

$=0.249(\mathrm{p}>0.05)$. This figure means that there are no similarities in the variants of the two variables.

Table 5.

Heteroscedasticity Test Results

\begin{tabular}{|c|c|c|c|c|c|c|}
\hline \multicolumn{7}{|c|}{ Coefficients } \\
\hline \multirow{2}{*}{\multicolumn{2}{|c|}{ Model }} & \multicolumn{2}{|c|}{$\begin{array}{l}\text { Unstandardized } \\
\text { Coefficients }\end{array}$} & \multirow{2}{*}{$\begin{array}{l}\text { Standardized } \\
\text { Coefficients } \\
\text { Beta }\end{array}$} & \multirow[t]{2}{*}{$\mathrm{t}$} & \multirow[t]{2}{*}{ Sig. } \\
\hline & & $\mathrm{B}$ & Std. Error & & & \\
\hline \multirow[t]{3}{*}{1} & (Constant) & 17.369 & 3.670 & & 4.733 & .000 \\
\hline & Self-Esteem & -.184 & .117 & -.177 & -1.575 & .119 \\
\hline & Pemaafan & -.053 & .046 & -.131 & -1.160 & .249 \\
\hline
\end{tabular}

a. Dependent Variable: ABS_RES

The last step was to calculate autocorrelation between research variables. Based on the test results carried out in the Runs Test table (shown in table 6), the Asymp Sig (2-tailed) value of 0.758 ( $\mathrm{p}>0.05$ ) was obtained, which means that there is no autocorrelation between research variables. Thus, multiple linear regression tests could be performed. The data was normal, linear, and heteroscedasticity did not occur. There was also no autocorrelation and multi-collinearity.

Table 6.

Autocorrelation Test Results

\begin{tabular}{lr}
\hline & Unstandardized Residual \\
\hline Test Value & -.02131 \\
\hline Cases $<$ Test Value & 47 \\
\hline Cases $>=$ Test Value & 48 \\
\hline Total Cases & 95 \\
\hline Number of Runs & 47 \\
\hline$Z$ & -.308 \\
\hline Asymp. Sig. (2-tailed) & .758 \\
\hline a. Median & \\
\hline
\end{tabular}

Researchers used multiple linear regression tests to determine the effect of self-esteem and forgiveness variables on the resilience of adults 
who were victims of bullying. Based on the ANOVA table (table 7), it was found that the two independent variables can predict independent variables based on the regression equation $[\mathrm{F}=45.114, \mathrm{p}<0.05)]$ and the significance value obtained was 0.000 ( $p<0.05)$. The degree of the two independent variables in predicting the dependent variable can be seen through R Square's value $=0.495$. It means that the two independent variables can predict the dependent variable by $49.5 \%$. Based on these coefficient figures, it can be concluded that self-esteem and forgiveness can predict resilience in victims of adult bullying with a predictive rate of $49.5 \%$.

Table 7.

Multiple Linear Regression Test Results

\begin{tabular}{ccccc}
\hline \multicolumn{5}{c}{ Model Summary } \\
\hline Model & R & R Square & Adjusted R Square & Std. The error of the Estimate \\
\hline 1 & $.704^{\mathrm{a}}$ & .495 & .484 & 10.13266 \\
\hline a. Predictors: (Constant), Pemaafan, Self-Esteem \\
\hline
\end{tabular}

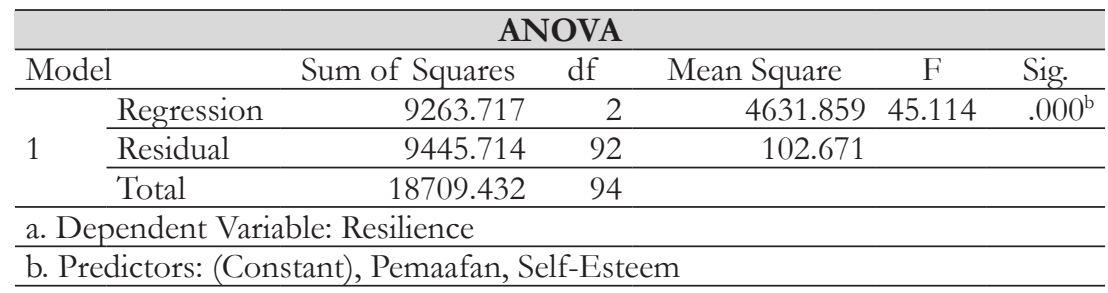

\section{Discussion}

This study aimed to determine the effect of forgiveness and selfesteem on the resilience of adult victims of bullying. The results of this study indicate that self-esteem and forgiveness can predict resilience in victims of adult bullying. The results of this study support some of the results of previous studies. Research conducted by Habibi and Hidayati (2018); Sharil, Abdullah, Rushdan, Jailani, and Mansor (2018); Sudirman, Suud, Rouzi, and Sari (2019); Worthington et al. (2016) proved that forgiveness 
is effective in increasing resilience in adolescent victims of bullying. Thus, forgiveness increases subjective well-being and psychological well-being (Daryanti, Yuwono, \& Sugiharto, 2020; Kirmani, 2015; Septarianda, Malay, \& Ulfah, 2020; Wulandari \& Megawati, 2020).

It is also evidenced by Kim and Lee (2014) that forgiveness therapy can increase resilience in wife who is a victim of husband's violence due to alcoholism, in addition to increasing self-esteem and spirituality. This research is also in line with Worthington Jr. and Scherer's (2004) finding which stated that forgiveness can affect the resilience and health conditions of individuals through good social support and the quality of their interpersonal relationships. Research by Saputro and Nashori (2017) conducted on student subjects also showed that forgiveness is a predictor of resilience. Habibi and Hidayati (2018) also mentioned that forgiveness of others has a positive correlation with resilience. It means that the more a person forgives others for the treatment they experience, the more likely he is to be resilient. Some of the studies above show that forgiveness can increase resilience across subject characteristics.

Individuals who are able to forgive others have been able to let go of various unpleasant things caused by interpersonal conflicts and seek to develop positive emotions, thoughts, and interpersonal relationships towards the person who has hurt them (Nashori, 2015; Wade, Hoyt, Kidwell, \& Worthington, 2014). Apart from that, forgiveness also affects the mood of the individual (Marks, Trafimow, Busche, \& Oates, 2013). Forgiveness will help someone to keep their mood stable and positive. In the end, resilience will be developed.

Forgiveness is not just an affidavit. Forgiveness is an attitude in which someone accepts that he is hurt, both physically and psychologically, and experiences injustice and then decides to let go of negative emotions and free oneself from the urge to punish and retaliate the behavior of those who hurt them (Brush, McGee, Cavanagh, \& Woodward, 2001). 
This means that victims of bullying who forgive the perpetrator no longer have negative emotions and thoughts. Negative emotions and thoughts will impair resilience. This is because negative emotions and thoughts will destabilize the individual's mental state thus, causing individual resilience level to decrease. However, when a victim of bullying forgives the bully, their emotions and thoughts become positive, and it will help them maintain a stable mental state (McCullough, 2001). In the end, the resilience will be preserved (Najam-us-Sahar \& Muzaffar, 2017).

The link between forgiveness and resilience can also be examined from several aspects of resilience. According to Reivich and Shatté (2002), resilience consists of seven aspects, namely emotional regulation, impulse control, optimism, empathy, analysis of causes of problems, self-efficacy, and improvement of positive aspects. Emotional regulation can be interpreted as an attitude related to attempt in reassessing the emotions and conditions experienced. Emotional regulation is characterized by a cognitive evaluation towards the stimuli obtained to influence experiences and change emotional expression. Because of it, the negative impact of emotions can be minimized (Chen, 2016; Gross, 2002). In the context of this research, bullying victims evaluate their experiences of being bullied. The evaluation causes victim to regulate their emotions. If the victim is angry, hateful, and resentful; it will hurt their mental condition. Thus, the victim of bullying realizes that the appropriate response is not to let negative emotions dominate oneself even though the bullying is a painful experience. Strategy that can be done so that negative emotions do not dominate them is forgiving the perpetrator. This way, forgiveness helps individuals to regulate emotions. The regulation of emotions affects resilience.

Forgiveness by the victim of bullying also helps them control their impulses (Burnette et al., 2014). Forgiveness helps the victim of bullying, not to vent out anger because forgiveness causes bullying victim to 
alter negative emotions and thoughts into more positive ones. Besides, forgiveness also helps the victim of bullying hold back anger to neutralize desire and urge to reciprocate the bullying behavior. Thus, the resilience level of bullying victim will be high when implementing forgiveness because their mental condition is not disturbed by harmful and destructive motivations.

Forgiveness is also closely related to self-efficacy. Forgiveness is found to play a vital role in self-efficacy (Griffin et al., 2015; Gençoğlu, Sahin, \& Topkaya, 2018). Self-efficacy is an individual's feeling and belief that they can face and solve their own problems (Bandura, 1977, 1997). When victims of bullying forgive the perpetrator, they have confidence that they can face the bullying problem. Forgiveness has caused them to improve the quality of their own self because forgiveness can only be done if the individual has the ability to forgive. Increasing the quality of oneself is a crucial modality to generate confidence that they are able to deal with bullying problems. On the other hand, forgiveness can affect self-efficacy. Self-efficacy can reduce the emergence of adverse effects in bullying victims, such as anxiety, stress, and depression (Gençoğlu et al., 2018). Therefore, forgiveness can play an essential role in the resilience of the victim of bullying.

Forgiveness done by victims of bullying causes the negative effects within them to turn into positive ones. The positive effects caused by forgiveness then possess an impact in increasing their psychological wellbeing and happiness (Karduz \& Saricam, 2018; Toussaint \& Friedman, 2008). When individuals have high psychological well-being and happiness, their resilience will increase. In this way, forgiveness can help the victim of bullying to cope.

Forgiveness also consists of three contexts, namely forgiving others, forgiving yourself, and forgiving situations and conditions (KJ, 2018). Victims of bullying who implement forgiveness do not only forgive the 180 
bully. They also forgive themselves, so they do not fall into self-blame. Some bullying victims are regretting and blaming themselves for being weak. This is because one of the factors in bullying is the perpetrator's perception that the victim of bullying is a weak person. However, if the victim of bullying does not blame their own self, forgives oneself, and does not think that their own condition is the cause of bullying, the mental condition will not be vulnerable. In the end, victims of bullying who forgive themselves have high resilience level.

Resilient individuals have an optimistic attitude and confidence in their faith, which leads them to bounce back, adapt, and feel optimistic (Connor \& Davidson, 2003). In the deepening phase, forgiving person is always looking for positive meanings behind what happens (Chaudhary, Jyoti, \& Chaudhary, 2014). The positive meaning is accompanied by the belief that the current conditions have wisdom, causing victims of bullying to believe that they are able to forgive. Persons who are able will face life optimistically and turn painful experiences into learning experiences rather than a focus on revenge (Kumar \& Dixit, 2014; Mary \& Patra, 2016). The expected effect is not only being able to forgive but also to have a forgiving nature to tolerate a condition that hurts them.

This study also supports the results of research conducted by Henriksen (2016) that self-esteem is a factor that affects resilience for someone who experiences anxiety and depression. These two conditions are closely related to the effect of bullying on victims (Hidayati \& Rahayuningsih, 2014). Balgiu (2017) also said that self-esteem is a predictor of resilience in adulthood. On the other hand, Djamahar, Dewahrani, and Octaviani (2020) indicated that self-esteem is negatively correlated with negative emotions in a person. This means that the higher a person's selfesteem, the lower the negative emotions in them. Someone who has high self-esteem can neutralize or eliminate negative emotions in their own self. A person understands that negative emotions will only make their 
condition worse. So, there is no other way to cultivate self-esteem except by getting rid of all negative emotions. Likewise, for victims of bullying, those who have positive self-esteem will be motivated to eliminate negative emotions resulting from bullying. In the end, they are not burdened by these negative emotions, so that their resilience is high.

As has been explained, one of the bullying causes is the bully perceives the victim as a weak and negative individual. This condition can have an impact bullying victim's self-concept. If their self-concept turns negative, the self-esteem will be affected. When victims of bullying have a negative self-concept, they will not respect themselves. More so if they believe the negative labels that are directed by the perpetrator to them. It can destroy their self-concept and self-esteem. However, if the perpetrator's perception of them does not influence the victim, their selfconcept will be preserved. This condition then has an impact on selfesteem, which remains positive. In the end, this positive self-esteem causes the victims of bullying to have high resilience.

A condition that is likely to occur in bullying victims is deteriorating self-esteem. Furthermore, this condition will result in the victim's vulnerability to anxiety, depression, and suicidal thoughts. This can happen because low self-esteem will cause individuals to lose hope. This condition then weakens resilience, resulting in various psychological disorders and suicidal thoughts (Karatas \& Cakar, 2011). Self-esteem can be defined as an individual's positive evaluation of one own self as a person who is capable and personal feelings that he is a valuable individual (Rosenberg, 1965; Coopersmith, 1967). Thus, positive self-esteem also indicates that a person can face the problems he encounter.

In the context of bullying, victims who have positive self-esteem will believe that they can face bullying problems. This belief then causes his endurance to be high. Therefore, victims of bullying who have positive self-esteem will become resilient individuals. On the other hand, research 
by Chung et al. (2018) and Kurniawan, Neviyarni, and Solfema (2018) also showed that self-esteem is positively correlated with individual resilience.

Self-esteem consists of four aspects, namely significance, power, virtue, and competence (Coopersmith, 1967). The significance aspect of self-esteem causes victims of bullying to feel worthy of respect. The one who can truly appreciate them is their own self. Thus, this significance aspect plays an essential role in preventing the victim of bullying from feeling meaningless or worthless. Thus, their mental condition and resilience will be healthy. Besides, victims of bullying who have high selfesteem are also develop virtue. Virtue as an aspect of self-esteem in bullying victim is characterized as not being compelled to retaliate against bullying behavior. The virtue is an attitude that seeks to avoid prohibited behavior and instead conduct behavior that is compulsory and recommended by norms. So, virtue encourages victims to forgive and not retaliate against the bullying. The established virtue then causes the victims of bullying to avoid negative emotions and thoughts, improve their self-esteem, which positively influence their resilience.

Regarding the competence aspect, victims of bullying believe that they can get past bullying problems. This belief causes victims to survive the bullying. On this basis, too, self-esteem which consists of belief in one's ability is correlated with self-efficacy. Good self-efficacy helps individuals increase resilience (Sagone \& Caroli, 2013), especially in victims of bullying.

Based on this description, the researcher realizes that there are still many limitations in this study, especially regarding the research subject. The number of subjects involved in this study was limited, only 94 subjects from the total of 117 subjects who filled the measuring instruments. A total of 23 subjects were eliminated because they did not match the research subject's criteria, and several items were dropped because they were not filled in. This is due to the limited control of researchers in 
online-based data collection. Besides, researchers conducted this research in the Yogyakarta area.

\section{CONCLUSION AND SUGGESTION}

\section{Conclusion}

Based on the results that have been obtained, it can be concluded that forgiveness and self-esteem influence resilience. The influence of both variables is quite considerable, amounting to $49.5 \%$ of variance. Victims of bullying who forgive the bully will be free from negative emotions. Thus, they are not susceptible to mental disorders and psychological burdens. The dispensation of these negative emotions can then positively prompt the development of resilience in them. Thus, the forgiveness of victims of bullying causes them to survive the bullying problem. Besides, the forgiveness of victims of bullying is aimed at the perpetrator and themselves. Thus, victims of bullying are not inclined to blame themselves. In the end, his resilience was not compromised.

Self-esteem is an overall evaluation of oneself that is an individual who is capable and needs to be valued. When victims of bullying have positive self-esteem, they would make a positive evaluation of their condition. This process causes them to respect themselves by persisting in the problem of bullying. This self-respect attitude prevents the victim of bullying from being influenced by the negative label that the bully has put on them. So, the psychological condition of bullying victims who have positive self-esteem is not burdened with these negative labels and behaviors. Besides, self-esteem also helps them increase the confidence so they can overcome the bullying problems. Thus, high self-esteem helps them to create high resilience as well. 


\section{Suggestion}

The researchers suggest that future researcher can advance this research by perfecting the limitations of this study. Researchers also suggest that future research can involve more subjects from various regions so that the data obtained will be more accurate. The broader research scope also helps future researchers to achieve universal results. In addition, future researchers will be able to develop this research by examining its association with other related topics.

This study also reinforces that forgiveness and self-esteem in victims of bullying can increase their resilience. Therefore, forgiveness and self-esteem can be a pressure point in dealing with victims of bullying. It implies that forgiveness and self-respect can be an essential part of psychotherapy for treating victims of bullying.

\section{REFERENCES}

Aalsma, M. C., \& Brown, J. R. (2008). What Is Bullying? Journal of Adolescent Health, 43(2), 101-102. https://doi.org/10.1016/j. jadohealth.2008.06.001

Azwar, S. (2016). Reliabilitas dan Validitas (4 Ed). Yogyakarta: Pustaka Pelajar.

Balgiu, B. A. (2017). Self-esteem, Personality, and Resilience: Study of A Students Emerging Adults Group. Journal of Educational Sciences \& Psychology, VII (LXIX)(1), 93-99.

Bandura, A. (1977). Self-Efficacy: Toward A Unifying Theory Of Behavioral Change. Psychological Review, 84, 191-215.

Bandura, A. (1997). Self-efficacy: The Exercise of Control. New York, USA: W H Freeman/Times Books/ Henry Holt \& Co.

Brush, B. L., McGee, E. M., Cavanagh, B., \& Woodward, M. (2001). Forgiveness: A Concept Analysis. Journal of Holistic Nursing, 19(1), 27-41. https:// doi.org/10.1177/089801010101900104 
Burnette, J. L., Davisson, E. K., Finkel, E. J., Tongeren, D. R. Van, Hui, C. M., \& Hoyle, R. H. (2014). Self-Control and Forgiveness: A Meta-Analytic Review. Social Psychological and Personality Science, 5(4), 443-450. https://doi.org/10.1177/1948550613502991

Cast, A. D., \& Burke, P. J. (2002). A Theory of Self-Esteem. Social Forces, 80(3), 1041-1068. https://doi.org/10.1353/sof.2002.0003

Chaudhary, H., Jyoti, \& Chaudhary, S. (2014). Positive Emotions, Resilience, Gratitude, and Forgiveness: Role of Positive Psychology in the 21 st Century. Indian Journal of Positive Psychology, 5(4), 528-530.

Chen, H. (2016). A Theoretic Review of Emotion Regulation. Open Journal of Social Sciences, 04(02), 147-153. https://doi.org/10.4236/ jss. 2016.42020

Chung, J. O. K., Lam, K. K. W., Ho, K. Y., Cheung, A. T., Ho, L. L. K., Gibson, F., \& Li, W. H. C. (2018). Relationships Among Resilience, Self-Esteem, and Depressive Symptoms in Chinese Adolescents. Journal of Health Psychology, 25(13-14), 2396-2405. https://doi. org/10.1177/1359105318800159

Connor, K. M., \& Davidson, J. R. T. (2003). Development of A New Resilience Scale: The Connor-Davidson Resilience Scale (CDRISC). Depression and Anxiety, 18, 76-82. https://doi.org/10.1002/ da.10113

Coopersmith, S. (1967). The Antecedents of Self-Esteem. San Francisco: W. H. Freeman \& Company.

Copeland, W. E., Wolke, D., Angold, A., \& Costello, E. J. (2013). Adult Psychiatric Outcomes of Bullying and Being Bullied by Peers in Childhood and Adolescence. JAMA Psychiatry, 70(4), 419-426. https://doi.org/10.1001/jamapsychiatry.2013.504

Daryanti, E. T., Yuwono, D., \& Sugiharto, P. (2020). Forgivingness and Subjective Well-Being of the Female Prisoners. Jurnal Bimbingan Konseling, 9(134), 79-85. https://doi.org/10.15294 /junk. v9i1.29126

Djamahar, R., Dewahrani, Y., R., \& Octaviani, R. (2020). Relationship Between Self-Esteem and Negative Emotional State with Academic Procrastination in Final Level Students. Indonesian Journal of Biology Education, 3(1), 6-12. https://doi.org/10.31002/ijobe.v3i1.2290 
Egan, L. A., \& Todorov, N. (2009). Forgiveness as a Coping Strategy to Allow School Students to Deal With the Effects of Being Bullied: Theoretical and Empirical Discussion. Journal of Social and Clinical Psychology, 28(2), 198-222. https://doi.org/10.1521/ jscp.2009.28.2.198

Gençoğlu, C., Şahin, E., \& Topkaya, N. (2018). General Self-Efficacy and Forgiveness of Self, Others, and Situations as Predictors of Depression, Anxiety, and Stress in University Students. Educational Sciences: Theory and Practice, 18(3), 605-626. https://doi. org/10.12738/estp.2018.3.0128

Griffin, B. J., Worthington Jr., E. L., Greer, C. L., Lin, Y., Davis, D. E., \& Hook, J. N. (2015). Efficacy of a Self-Forgiveness Workbook: A Randomized Controlled Trial With Interpersonal Offenders. Journal of Counseling Psychology, 62(2), 124-136. https://doi. org $/ 10.1037 / \operatorname{cou} 0000060$

Gross, J. J. (2002). Emotion Regulation: Affective, Cognitive, and Social Consequences. Psychophysiology, 39, 281-291. https://doi. org/10.1017.S0048577201393198

Habibi, M. M., \& Hidayati, F. (2018). Hubungan Antara Pemaafan Diri Sendiri, Pemaafan Orang Lain, Dan Pemaafan Situasi Dengan Resiliensi Pada Mahasiswa Baru (Studi Korelasi Pada Mahasiswa Baru Universitas Diponegoro Semarang). Empati, 6(2), 62-69.

Hatta, M. (2018). Tindakan Perundungan (Bullying) Dalam Dunia Pendidikan Ditinjau Berdasarkan Hukum Pidana Islam. MIQOT: Jurnal Ilmu-Imu Keislaman, 41(2), 280-301. https://doi. org/10.30821/miqot.v41i2.488

Henriksen, I. O. (2016). Self-Esteem as a Resilience Factor for Symptoms of Anxiety, Depression, and Attention Problems: Evidence from A Clinical Population of Adolescents. Graduate Thesis in Medicine NTNU, 1-15.

Henriksen, I. O., Ranøyen, I., Indredavik, M. S., \& Stenseng, F. (2017). The Role of Self-esteem in the Development of Psychiatric Problems: A Three-year Prospective Study in A Clinical Sample of Adolescents. Child and Adolescent Psychiatry and Mental Health, 11(68), 1-9. https://doi.org/10.1186/s13034-017-0207-y 
Herrman, H., Stewart, D. E., Diaz-Granados, N., D, E. L. B., Jackson, B., \& Yuen, T. (2011). What Is Resilience? The Canadian Journal of Psychiatry, 56(5), 258-265.

Hidayati, N., \& Rahayuningsih, I. (2014). Bentuk Dan Dampak Kekerasan Di Tempat Kerja (Workplace Bullying) Pada Buruh Pabrik Di Gresik. Jurnal Psikosains, 9(2), 125-139.

Jaufalaily, N., \& Himam, F. (2017). Resilience as a Mediator of the Relationship Between Forgiveness and Happiness Among College Student. Anima Indonesian Psychological Journal, 32(3), 121-127. https://doi.org/10.24123/aipj.v32i3.626

Kaplan, R. M., \& Saccuzzo, D. P. (2017). Psychological Testing: Principles, Applications, and Issues (9th Ed). Australia: Cengage Learning.

Karatas, Z., \& Cakar, F. S. (2011). Self-Esteem and Hopelessness, and Resiliency: An Exploratory Study of Adolescents in Turkey. InternationalEducation Studies, 4(4), 84-91.https://doi.org/10.5539/ ies.v4n $4 \mathrm{p} 84$

Karduz, F. F. A., \& Saricam, H. (2018). The Relationships between Positivity, Forgiveness, Happiness, and Revenge. Revista Românească Pentru Educatie Multidimensională, 10(4), 1-22. https://doi.org/10.18662/ $\mathrm{rrem} / 68$ The

Kim, H. K., \& Lee, M. (2014). Effectiveness of Forgiveness Therapy on Resilience, Self-esteem, and Spirituality of Wives of Alcoholics. Journal of Korean Academy of Nursing, 44(3), 237-247. https://doi. org/10.4040/jkan.2014.44.3.237

Kirmani, M. N. (2015). Gratitude, Forgiveness, and Subjective-well-being Among College Going Students. International Journal Of Public Mental Health And Neurosciences, 2(2), 1-10.

KJ, L. (2018). Forgiveness: Definitions, Perspectives, Contexts, and Correlates. Journal of Psychology \& Psychotherapy, 08(03), 1000342. https://doi.org/10.4172/2161-0487.1000342

Kumar, A., \& Dixit, V. (2014). Forgiveness, Gratitude, and Resilience Among Indian Youth. Indian Journal of Health and Wellbeing, 5(12), 1414-1419.

Kurniawan, B., Neviyarni, N., \& Solfema, S. (2018). The Relationship Between Self-Esteem and Resilience of Adolescents who Living in Orphanages. International Journal of Research in Counseling and 
Education, 1(1), 47-52. https://doi.org/10.24036/0054za0002

Kwek, A., Bui, H. T., Rynne, J., \& So, K. K. F. (2013). The Impacts of Self-Esteem and Resilience on Academic Performance: An Investigation of Domestic and International Hospitality and Tourism Undergraduate Students. Journal of Hospitality, 23, 110 122. https://doi.org/10.1080/10963758.2013.826946

Marks, M. J., Trafimow, D., Busche, L. K., \& Oates, K. N. (2013). A Function of Forgiveness: Exploring the Relationship Between Negative Mood and Forgiving. SAGE Open, 1-9. https://doi. org $/ 10.1177 / 2158244013507267$

Mary, E. M., \& Patra, S. (2016). Relationship between Forgiveness, Gratitude, and Resilience among the Adolescents. Indian Journal of Positive Psychology, 6(1), 63-68.

McCullough, M. E. (2001). Forgiveness: Who Does It and How Do They Do It? Current Directions in Psychological Science, 10(6), 194-197. https://doi.org/10.1111/1467-8721.00147

Min, J. A., Lee, N. Bin, Lee, C. U., Lee, C., \& Chae, J. H. (2012). Low Trait Anxiety, High Resilience, and Their Interaction as Possible Predictors for Treatment Response in Patients With Depression. Journal of Affective Disorders, 137(1-3), 61-69. https://doi. org/10.1016/j.jad.2011.12.026

Nagra, G. S., Lin, A., \& Upthegrove, R. (2016). What Bridges the Gap Between Self-harm and Suicidality? The Role of Forgiveness, Resilience, and Attachment. Psychiatry Research, 241, 78-82. https:// doi.org/10.1016/j.psychres.2016.04.103

Najam-us-Sahar, \& Muzaffar, N. (2017). Role of Family System, Positive Emotions, and Resilience in Social Adjustment among Pakistani Adolescents. Journal of Educational, Health, and Community Psychology, 6(2), 46-58.

Nashori, F. (2015). Psikologi Pemaafan. Yogyakarta: Safiria Insania Press.

Prasetyo, A. B. E. (2014). Bullying di Sekolah dan Dampaknya bagi Masa Depan Anak. El-Tarbawi, 4(1), 19-26. https://doi.org/10.20885/ tarbawi.vol4.iss1.art2

Reivich, K., \& Shatté, A. (2002). The Resilience Factor: 7 Essential Skills for Overcoming Life's Inevitable Obstacles. New York, New York, United States: Broadway Books. 
Rosenberg, M. (1965). Society and the Adolescent Self-Image. Princeton, New Jersey: Princeton University Press.

Saffarinia, M., Mohammadi, N., \& Afshar, H. (2016). The Role of Interpersonal Forgiveness in Resilience and Severity of Pain in Chronic Pain Patients. Fundamentals of Mental Health, 18(4), 212 219.

Sagone, E., \& Caroli, M. E. De. (2013). Relationships between Resilience, Self-Efficacy, and Thinking Styles in Italian Middle Adolescents. Procedia - Social and Behavioral Sciences, 92, 838 - 845. https://doi. org/10.1016/j.sbspro.2013.08.763

Saifuddin, A. (2019). Penelitian Ekesperimen Dalam Psikologi. Jakarta: Kencana. Saifuddin, A. (2020). Penyusunan Skala Psikologi. Jakarta: Kencana.

Saputro, I., \& Nashori, F. (2017). Resiliensi Mahasiswa Ditinjau dari Pemaafan dan Sifat Kepribadian Agreeableness. Jurnal Psikologi Islam, 4(2), 171-180.

Schmitt, D. P., \& Allik, J. (2005). Simultaneous administration of the Rosenberg Self-Esteem Scale in 53 Nations: Exploring the Universal and Culture-Specific Features of Global Self-Esteem. Journal of Personality and Social Psychology, 89(4), 623-642. https:// doi.org/10.1037/0022-3514.89.4.623

Septarianda, E., Malay, M. N., \& Ulfah, K. (2020). Hubungan Forgiveness dengan Subjective Well-Being pada Remaja di Panti Asuhan. Jurnal Psikologi Malahayati, 2(1), 83-91. https://doi.org/10.33024/jpm. v211.2488

Sharil, H., Abdullah, L. I. M., Rushdan, M., Jailani, M., \& Mansor, S. (2018). Forgiveness and Resilience Among Staff in the Government Drug Treatment and Rehabilitation. International Journal of Management and Applied Science, 4(5), 1-5.

Smith, P. K. (2016). Bullying: Definition, Types, Causes, Consequences, and Intervention. Social and Personality Psychology Compass, 10(9), 519-532. https://doi.org/10.1111/spc3.12266

Soni, P. (2015). A Study on the Relationship Between Resilience and Forgiveness. Indian Journal of Mental Health(IJMH), 3(1), 57-61. https://doi.org/10.30877/ijmh.3.1.2016.57-61

Southwick, S. M., Bonanno, G. A., Masten, A. S., Panter-Brick, C., \& Yehuda, R. (2014). Resilience Definitions, Theory, and Challenges: 
Interdisciplinary Perspectives. European Journal of Psychotraumatology, 5, 1-14. https://doi.org/10.3402/ejpt.v5.25338

Sudirman, S. A., Suud, F. M., Rouzi, K. S., \& Sari, D. P. (2019). Forgiveness and Happiness Through Resilience. Al-Qalb: Jurnal Psikologi Islam, 10(2), 113-132.

Thompson, L. Y., Snyder, C. R., Hoffman, L., Michael, S. T., Rasmussen, H. N., Billings, L. S., , . Roberts, D. E. (2005). Dispositional Forgiveness of Self, Others, and Situations. Journal of Personality, 73(2), 314 360. https://doi.org/10.1111/j.1467-6494.2005.00311.x

Toussaint, L., \& Friedman, P. (2008). Forgiveness, Gratitude, and WellBeing: The Mediating Role of Affect and Beliefs. Journal of Happiness Studies, 10(6), 635-654. https://doi.org/10.1007/ s10902-008-9111-8

Veselka, Z., Geckova, A. M., Orosova, O., Gajdosova, B., van Dijk, J. P., \& Reijneveld, S. A. (2009). Self-esteem and Resilience: The Connection with Risky Behavior Among Adolescents. Addictive Behaviors, 34(3), 287-291. https://doi.org/10.1016/j.addbeh.2008.11.005

Wade, N. G., Hoyt, W. T., Kidwell, J. E. M., \& Worthington, E. L. (2014). Efficacy of Psychotherapeutic Interventions to Promote Forgiveness: A Meta-Analysis. Journal of Consulting and Clinical Psychology, 82(1), 154-170. https://doi.org/10.1037/a0035268

Watson, H., Rapee, R., \& Todorov, N. (2015). Forgiveness Reduces Anger in a School Bullying Context. Journal of Interpersonal Violence, 32(11), 1642-1657. https://doi.org/10.1177/0886260515589931

Wolke, D., \& Lereya, S. T. (2015). Long-term Effects of Bullying. Archives of Disease in Childhood, 100, 879-885. https://doi.org/10.1136/ archdischild-2014-306667

Woods, S., Wolke, D., Nowickic, S., \& Hall, L. (2009). Emotion Recognition Abilities and Empathy of Victims of Bullying. Child Abuse and Neglect, 33, 307-311. https://doi.org/10.1016/j. chiabu.2008.11.002

Worthington, E. L., Griffin, B. J., Toussaint, L. L., Nonterah, C. W., Utsey, S. O., \& Garthe, R. C. (2016). Forgiveness as A Catalyst for Psychological, Physical, and Spiritual Resilience in Disasters and Crises. Journal of Psychology and Theology, Vol. 44, pp. 152-165. https://doi.org/10.1177/009164711604400206 
Worthington Jr, E. L., \& Scherer, M. (2004). Forgiveness Is An Emotion-Focused Coping Strategy That Can Reduce Health Risks And Promote Health Resilience: Theory, Review, And Hypothesis. Psychology \& Health, 19(3), 385-405. https://doi. org/10.1080/0887044042000196674

Wulandari, I., \& Megawati, F. E. (2020). The Role of Forgiveness on Psychological Well-Being in Adolescents: A Review. Advances in Social Science, Education and Humanities Research, 99-103. https:/ / doi. org/10.2991/assehr.k.200120.022

Zhang, C. (2017). Forgiveness Among College Students with Past Bullying Victimization Experiences. Dissertation Boston University, 1-119. 